\title{
Cutaneous Squamous Cell Carcinoma of the Head and Neck pT3 TNM Finding v8
}

National Cancer Institute

\section{Source}

National Cancer Institute. Cutaneous Squamous Cell Carcinoma of the Head and Neck pT3 TNM Finding v8. NCI Thesaurus. Code C133208.

Cutaneous squamous cell carcinoma of the head and neck with tumor $4 \mathrm{~cm}$ or larger in greatest dimension or minor bone erosion or perineural invasion or deep invasion. Deep invasion is defined as invasion beyond the subcutaneous fat or larger than $6 \mathrm{~mm}$; perineural invasion for T3 classification is defined as tumor cells within the nerve sheath of a nerve lying deeper than the dermis or measuring $0.1 \mathrm{~mm}$ or larger in caliber, or presenting with clinical or radiog raphic involvement of named nerves without skull base invasion or transgression. (from AJCC 8th Ed.) 